\title{
A Post-occupancy Evaluation of the Influence of Wood on Environmental Comfort
}

\author{
Mélanie Watchman,* André Potvin, and Claude M. H. Demers \\ Emerging research on the impact of interior finishes, more specifically \\ wood, is beginning to shed light on informed design opportunities. As a \\ natural building material with unique features, wood creates warm and \\ pleasant atmospheres and has the potential of enhancing the well-being \\ of occupants. This research attempted to better understand how \\ occupants perceive wood in built environments and whether its indoor \\ use influenced the satisfaction of occupants. The comfort of occupants \\ may have been influenced by factors that were unrelated to the indoor \\ environmental quality, which caused difficulties in comparing interior \\ finishes in existing environments and limited research in this field. An \\ exploratory comparative study, within a post-occupancy evaluation \\ framework, investigated the subjective perception of occupants in \\ relation to physical comfort factors. Thirty-six occupants completed a \\ questionnaire to examine comfort satisfaction in a multifunctional room \\ with extensive wooden interior finishes in comparison with a similar \\ space without wood surfaces. The results indicated that occupants were \\ more satisfied in the extensive wood surfaced room in terms of lighting, \\ noise, and temperature, despite the similar environmental conditions in \\ both spaces. Adjectives often used to describe the wood room included \\ bright, pleasant, modern, and warm. Architects should consider the \\ subjective qualities of wood when designing comfortable buildings.
}

Keywords: Indoor environmental quality; Occupant comfort; Post-occupancy evaluation; Questionnaire; Interior wood finishes

Contact information: School of Architecture, Laval University, 1 Cote de la Fabrique, Quebec, GIK 7P4, Canada; *Corresponding author: melanie.watchman.1@ulaval.ca

\section{INTRODUCTION}

In architecture, materials have the potential to minimise the feeling of disconnection between nature and built environments. Natural interior finishes, such as wood, have the possibility of emphasising the character and attractiveness of a space. Few studies have focused on the well-being of occupants and the indoor use of organic materials, such as wood (Nyrud and Bringslimark 2010; Augustin and Fell 2015; Burnard and Kutnar 2015). In a comparative study of four simulated office environments, Fell (2010) determined that wood in built environments reduces the stress of occupants and is perceived as natural and warm. Rice et al. (2006) determined that wood finishes, in comparison with industrial and synthetic finishes, increase the psychological well-being of occupants. The positive perception of wood exceeded the other finishes for the adjectives warm, natural, relaxing, and inviting. Participants perceived wood as less modern, industrial, and artificial, and more stylish and contemporary compared with the other materials. Tsunetsugu et al. (2007) determined that distinct wood quantities generate diverse physiological responses. In three $13-\mathrm{m}^{2}$ rooms with $0 \%, 45 \%$, and $90 \%$ 
wood finishes, 15 participants considered the wood rooms to be natural and the room without wood finishes to be artificial. The room with $45 \%$ wood finishes was perceived to be more comfortable and restful than the others, which suggested that an optimal quantity of wood in interior environments may exist. The effects of wood on the comfort of occupants have rarely been documented in built environments, where comfort parameters can fluctuate. This can be explained by the difficulty of identifying existing identical rooms that diverge only in their interior finishes to evaluate how different interior finishes influence the comfort satisfaction of occupants. A previous study by the authors compared thermal, acoustic, and visual comfort parameters in two multifunctional rooms without the presence of occupants. This study builds on previous work and focuses on the effects of interior wood finishes on comfort perception in the same rooms.

Environmental comfort emerges from a combination of thermal, visual, acoustic, and olfactory parameters. Factors unrelated to these indoor environmental parameters, such as building features, personal characteristics, and work-related variables, can also affect comfort (Schiavon and Altomonte 2014). An analysis of occupant satisfaction in US office buildings over 10 years at the Center for the Built Environment showed that the most important aspect for occupant satisfaction is the amount of space, followed by the noise level, and visual privacy (Frontczak et al. 2012). These studies analysed data that were collected through industry recognised post-occupancy evaluation (POE) surveys.

A POE consists of 'the process of evaluating buildings in a systematic and rigorous manner after they have been built and occupied for some time' (Preiser et al. 1988). Several aspects of building performance are easily quantifiable, such as light, noise, temperature, and humidity, but POEs do not typically gather instrumental measurements with regards to the interior environmental conditions. This can lead to unfounded complaints against the building (Deuble and de Dear 2014). The Building Use Studies (BUS) occupant survey, Center for the Built Environment (CBE) survey, and Building Occupants Survey System Australia (BOSSA) are industry recognised POE surveys that are in use today (Peretti and Schiavon 2011; Galatioto et al. 2013; Candido et al. 2016). Current POE surveys pay little attention to interior finishes. The only question in the $\mathrm{CBE}$ survey that concerns finishes is the occupant satisfaction in relation to the colours and textures of the floor, furniture, and surface finishes. These surfaces are not documented, which hinders the study of the effect of particular finishes on satisfaction. The BUS and BOSSA surveys integrate questions about the image and overall design of the building, but they do not specifically address architectural components, such as interior finishes. With the available surveys, it is not possible to study the influence of certain interior finishes on occupant satisfaction and perception in buildings in a post-occupancy framework.

This research aims to incorporate specific questions regarding interior surfaces in a POE to explore how different interior finishes influence the satisfaction of occupants. The objectives of this pilot study were twofold; namely, the determination of the perception of interior wood finishes in built environments compared with other finishes, and the evaluation of occupant satisfaction with regards to the thermal, visual, acoustic, and olfactory parameters in a room with interior wood finishes and a similar room without wood. Based on previous studies on the psychophysiological effects of wood, it was hypothesised that occupants would use the adjectives natural, warm, and inviting to describe the wood room but not the non-wood room. Higher visual, air quality, acoustic, and temperature scores were predicted for the wood room. 


\section{EXPERIMENTAL}

This exploratory research provided the opportunity to expand on the current knowledge of the perception of wood in comparison with other types of interior finishes in buildings. The occupant satisfaction in two multifunctional rooms was evaluated by the self-assessed comfort perception of the occupants and concurrent measurements of the indoor environment.

\section{Materials}

Questionnaire

The present exploratory research on the influence of wood in relation to environmental comfort was innovative by introducing a series of questions into an industry-validated POE survey. The questions were inspired from past research on wood perception. Most research in the field of wood perception has been conducted in laboratory settings, while the study of interior finishes in POEs is limited. Therefore, the research consisted of a new survey that was specifically adapted to produce highly valuable findings on the preferences of occupants in relation to the use of indoor wood finishes in architecture. The study necessitated the development of an original questionnaire, because the perception of natural finishes in existing spaces is still in its embryonic stages. Table 1 presents the origin of the survey questions for the five sections of the newly designed questionnaire that allowed the study of the preferences of the building occupants at a scale smaller than the whole building. Questions relating to the perceptions of the materials engaged occupants in evaluating the effects and importance of certain characteristics used to describe the rooms. To study the subjective evaluation of the rooms, a list of adjectives was composed that were selected from relevant previous wood studies in experimental settings (Table 2).

Table 1. Origin of the Questionnaire Sections

\begin{tabular}{|l|c|c|c|}
\hline \multicolumn{1}{|c|}{ Questionnaire Section } & $\begin{array}{c}\text { Related Wood } \\
\text { Studies }\end{array}$ & CBE Survey & BUS Survey \\
\hline 1- Qualitative description of the rooms & $\bullet$ & & \\
\hline 2- Perception of interior finishes & & $\bullet$ & \\
\hline 3- Occupant perception of comfort & & & $\bullet$ \\
\hline 4- Satisfaction with the rooms in general & & & $\bullet$ \\
\hline 5- Participant demographics & & & $\bullet$ \\
\hline
\end{tabular}

Table 2. Adjectives Evaluating Wood Perception Based on Previous Studies

\begin{tabular}{|c|c|c|c|c|c|}
\hline \multirow[b]{2}{*}{ Adjectives } & \multicolumn{5}{|c|}{ Studies } \\
\hline & Fell (2010) & $\begin{array}{c}\text { Tsunetsugu et } \\
\text { al. (2007) }\end{array}$ & $\begin{array}{c}\text { Rice et al. } \\
(2006)\end{array}$ & $\begin{array}{l}\text { Ridoutt et al. } \\
\quad(2002)\end{array}$ & $\begin{array}{c}\text { Broman } \\
(2001)\end{array}$ \\
\hline Warm & - & & - & & - \\
\hline Restful & - & $\bullet$ & & $\bullet$ & - \\
\hline Modern & - & & & & \\
\hline Artificial & - & & - & & - \\
\hline Inviting & & & - & & \\
\hline Healthy & - & & & & \\
\hline Natural & - & - & - & & \\
\hline Comfortable & & - & & - & \\
\hline
\end{tabular}


The list included the following adjectives: warm, restful, modern, artificial, inviting, healthy, natural, comfortable, bright, pleasant, safe, stimulating, functional, and sustainable. These adjectives covered a wide array of impressions, which enabled a rich discussion on the integration of wood in interior spaces.

The self-assessed perception of the interior finishes of the occupants focused on their satisfaction with the quality, durability, and general appearance of the surfaces in the rooms. A question inspired from the CBE survey was included to evaluate the satisfaction level of the occupants with regards to the colours and textures of the furniture, floor, and walls. The section entitled Occupant Perception of Comfort gave respondents the opportunity to express their satisfaction with the lighting, ventilation, noise, and temperature conditions in the room. The BUS occupant survey was selected as a model for this exploratory survey. Developed by the Usable Buildings Trust from 30 years of building evaluation, this questionnaire extracts a wide range of information with a minimum number of questions (BUS Methodology 2016). Closed questions reduce answering time, but comment boxes allow participants to provide additional explanations on some topics. The BUS survey was adapted to the design of this study and was conducted on a 'right-here-right-now' basis to compare occupant responses with instrumental measurements of the indoor environment of the rooms. This type of survey allowed for a reliable analysis of the correlation between the comfort ratings of the occupants and conditions of the indoor environment, which was contrary to POE surveys that record occupant perceptions based on past seasons (Deuble and de Dear 2014). Questions with regards to the satisfaction with the rooms in general covered the following topics: overall design, commodities, image, space use, and cleanliness. The last portion of the questionnaire contained demographic questions, such as age, gender, if the building is part of the normal workplace of the occupant, when the occupant last worked or attended meetings in the building, professional field of the occupant, and which side of the room the respondent occupied during completion of the questionnaire.

\section{Participants}

The participants selected offered the advantage of regularly using both rooms in this comparative study. The teachers' union of Laval University draws 60 delegates from various departments and faculties, and holds meetings on Fridays between 11:30 am and $2 \mathrm{pm}$ in one of two multifunctional rooms located on campus. On April 15 ${ }^{\text {th }}, 2016$ under generally clear and sunny skies, 49 members attended the meeting held in the room with wooden interior finishes in the Gene-H.-Kruger building (Figs. 1a and 2a). Thirty-four of these members completed the questionnaire, resulting in a response rate of $69.4 \%$. A week later on April 22 $2^{\text {nd }}, 2016$ under overcast skies, a meeting took place in a room without interior wood finishes in the Alphonse-Desjardins building (Figs. 1b and 2b). Of the 59 people present, 36 of them completed the questionnaire, resulting in a $61 \%$ response rate. The response rates exceeded the American Society of Heating, Refrigerating and Air-conditioning Engineers (ASHRAE) (2013) 35\% recommended ratio for when more than 45 occupants are solicited. The rooms are only referred to as 'wood room' and 'non-wood room' in the analysis to avoid biasing the participants regarding whether or not wood was involved. In the questionnaire each room is referred to as 'the room you are currently in' or 'this room'. 


\section{Case study rooms}

Architectural perception results from more than the sum of the parts of a building. This is because experienced space transcends geometry and the measurable field. However, when choosing existing rooms in which the perception of interior finishes and occupant comfort can be compared, the quantifiable characteristics of a space were important considerations. The selection criteria of the rooms included the use of different finishes where interior wood finishes are only present in one of the rooms, similar physical dimensions, same purpose, identical window orientation, and the possibility for the spaces to be evaluated by the same group of occupants. The multifunctional rooms that possessed these conditions were located in two buildings on the main campus of Laval University in Quebec City, Canada (Fig. 1). Given the difficulty of identifying identical rooms in close proximity that the same participants could evaluate without resorting to a laboratory setting, it was acknowledged that when comparing existing spaces, differences other than interior finishes would arise, which were taken into consideration during the data analysis. The complexity of inhabiting an existing space was however recognised as promising in terms of perceived ambiance and the potential identification of sensations of well-being and connection with nature in relation to wood.

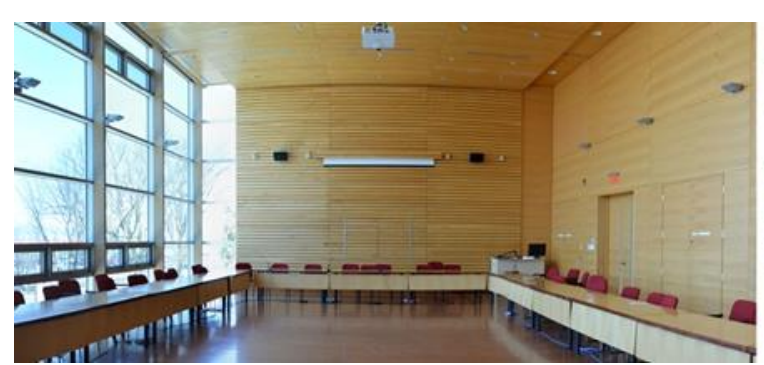

(a)

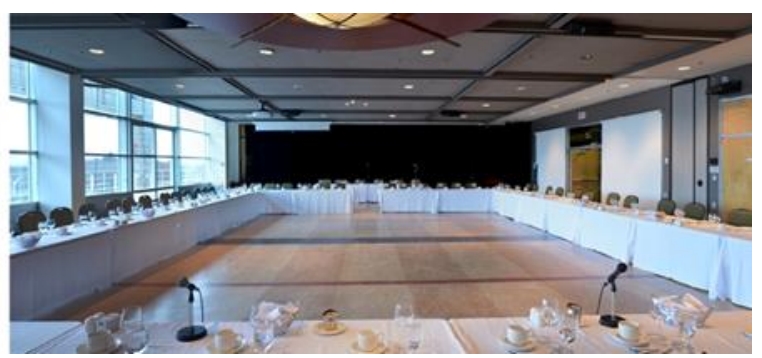

(b)

Fig. 1. Photographs of the wood room (a) and non-wood room (b) before the meetings

The diversity and contrasting use of interior finishes represented the most important distinction between the rooms for this study. The wood room, located in the Gene-H.-Kruger building, incorporated $87 \%$ wood interior finishes and included a variety of wood essences, such as yellow birch decorative wall panels, yellow birch ceiling slats, and sugar maple floorboards. The non-wood room, located in the Alphonse-Desjardins building, contained a multitude of interior finishes, including linoleum flooring, painted gypsum walls, perforated steel acoustic panels, a retractable polyvinyl chloride (PVC) partition, and black wall curtain, and less than $3 \%$ wood finishes. The colour of the materials and wood finishes produced spaces with distinct and contrasting ambiances, which should result in specific experiences. In that regard, Potvin (2000) mentioned that 'the experience of space in architecture is dynamic with periodic or constant movement between areas of a building or between inside and outside'. It was therefore also important that the materials used throughout the chosen buildings reflected the distinction of materials between the rooms. The rooms chosen for this study had similar physical dimensions. The floor area of the wood room $\left(204 \mathrm{~m}^{2}\right)$ was $14.3 \%$ smaller than in the non-wood room $\left(238 \mathrm{~m}^{2}\right)$. However, perceived available space per person may be more important than the amount of space physically available (Frontczak et al. 2012; Marans and Yan 1989). Despite the difference in floor area between the rooms, similar occupant density occurred during the meetings in the wood (4.16 $\mathrm{m}^{2} /$ person) and non-wood (4.03 
$\mathrm{m}^{2} /$ person) rooms. Further similarities between the rooms included a single window-wall that faced north-west. The window-to-floor ratio of the wood room (47.4\%) exceeded that of the non-wood room (17.9\%) because of differing window areas. The ceiling height $(5.4 \mathrm{~m})$ and window area $\left(96.7 \mathrm{~m}^{2}\right)$ in the wood room exceeded the ceiling height $(3.4 \mathrm{~m})$ and window area $\left(42.7 \mathrm{~m}^{2}\right)$ of the non-wood room. The position of the tables and chairs during the meetings consisted of an open rectangular pattern with a row of seats set aside for invited visitors (Fig. 2).

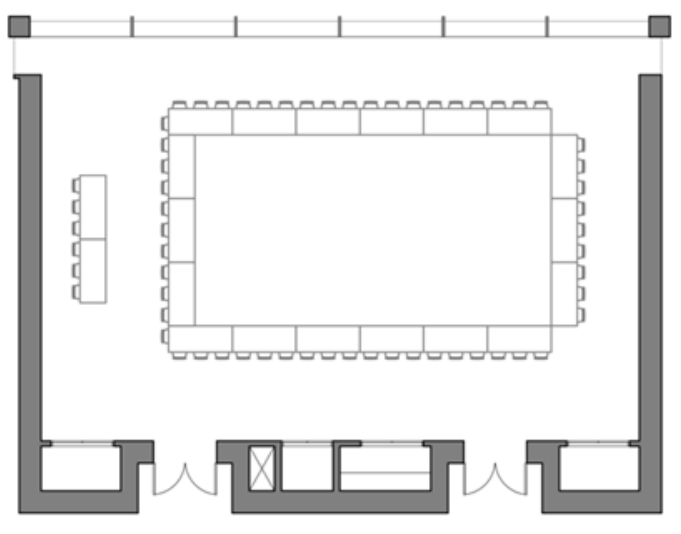

(a)

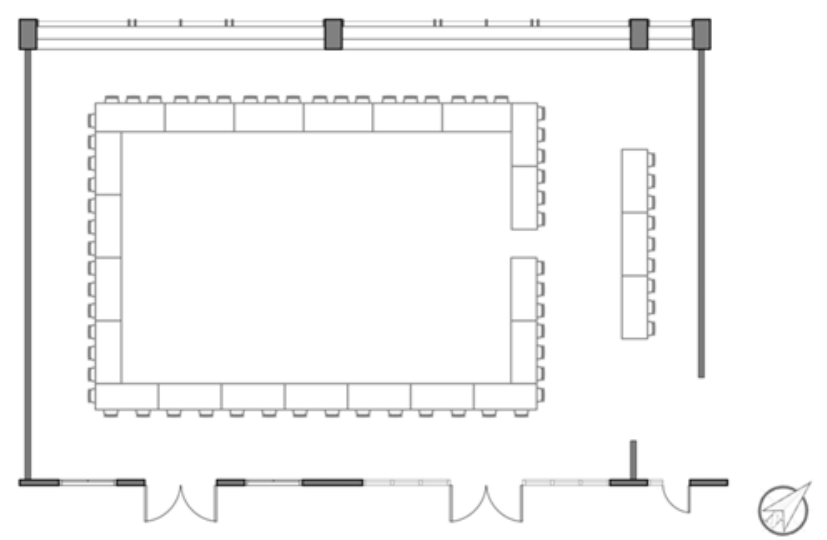

(b)

Fig. 2. Layout of the tables in the wood (a) and non-wood (b) rooms; scale 1:150

\section{Methods}

\section{Instrumental measurements}

The quantitative assessment of an environment provides parameters that can be matched against subjective observations. Demers and Potvin (2016) explained that 'existing spaces offer the advantage to experience actual ambiences in real time, enabling to assess quantitative parameters as well as qualitative ones'. The instrumental survey measurements were obtained using the same survey tools that were used by Watchman et al. (2017) in a quantitative study of these rooms. A multimeter (Environmental Meter EN100, Extech Instruments by FLIR Systems Inc., Nashua, USA) measured the air temperature, relative humidity, and illuminance data at a height of $1.1 \mathrm{~m}$ from the floor. An infrared laser thermometer (IR Thermometer- 62max+, FLUKE, Everett, USA) recorded the temperatures of the floor, wall, ceiling, and window surfaces. A thermohygro-NDIR $\mathrm{CO}_{2}$ meter (TES Electrical Electronic Corp., Taipei, Taiwan) read the indoor carbon dioxide concentrations. The Faber Acoustical SoundMeter application for iPhone/iPad/iPod touch (Faber Acoustical LLC., Lehi, USA) documented the noise levels in the rooms. The combination of measurements at nine locations in each room over a 20min interval determined the mean indoor values. The nearest meteorological station (Quebec Lesage International Airport) provided information on the outdoor weather conditions. Photographs of the rooms taken with a Canon EOS Rebel T3i (Canon Inc., Tokyo, Japan) were analysed in Adobe Photoshop (CS6, Adobe Systems Inc., San Jose, USA). The colour temperatures of the photographs were analysed and numerically described by the CIE $L^{*} a^{*} b^{*}$ colour model in Adobe Color CC (Adobe Systems Inc.). Used by the International Commission on Illumination (CIE), the $b^{*}$ values indicate the relative position of a colour between warm yellow $(+100)$ and cold blue $(-100)$ values. 


\section{Procedure}

A standard POE procedure was used to collect the subjective perception of the occupants of the rooms concurrently with instrumental measurements. The analysis of the comfort level of the occupants and their perceptions of the case study rooms required a direct recruitment of participants to complete the questionnaire. Thus, the project sought and received the approval of Laval University's Ethics Board (approval number: 2016063/07-04-2016). The occupants received prior warning of the study via an email sent by the board to its members. Although participants received sufficient information about the objectives and procedure of the study, they were not aware of any specific interest in wood products to avoid bias. Measurements of the indoor environmental conditions took place between 11 am and $12 \mathrm{pm}$. During this time, occupants completed the questionnaire that had been placed on the tables before their arrival. The researcher was not present in each room after $12 \mathrm{pm}$ because of the confidential nature of the topics discussed by the participants at the meetings. The occupants were invited to complete the survey before the meetings to avoid their evaluation of the rooms being positively or negatively influenced by the nature of the discussions.

\section{Data analysis}

Analysis of the questionnaire data attempted to describe the differences between the perceptions of the occupants of both rooms in this case study. A finite amount of statistical analyses was performed because of the exploratory nature of this architectural study and its restricted sample size. Despite the presence of the same group of participants in both of the rooms, an answer of a participant in the wood room may not necessarily be linked or paired with an answer in the non-wood room. The Shapiro-Wilk test assessed the normality of the score distributions by comparing 'the scores in the sample to a normally distributed set of scores with the same mean and standard deviation' (Ghasemi and Zahediasl 2012). A significance value above 0.05 indicated normality of the sample. The violation of the normality assumption should not create major problems when sample sizes are large enough (n > 30) (Elliot and Woodward 2007; Pallant 2016). The independent t-test compared mean votes in sections one and two of the questionnaire. The Mann-Whitney test verified differences in occupant answers in sections three and four of the questionnaire. For all of the tests, the analysis was conducted with the Statistical Package for the Social Sciences (SPSS) software (IBM Corp., Armonk, USA), and the results were considered statistically significant when $\mathrm{p}$ was less than 0.05 .

\section{RESULTS AND DISCUSSION}

\section{Qualitative Description of the Rooms}

Assessing the interior finishes in a POE framework allowed for the perception of the occupants in a wood building to be compared with wood perceptions expressed by participants in laboratory studies. The respondents were asked to determine how well 14 adjectives described the multifunctional room they occupied for each meeting. The evaluation of every attribute varied from 1 (does not describe the room well) to 7 (describes the room very well) (Fig. 3). 


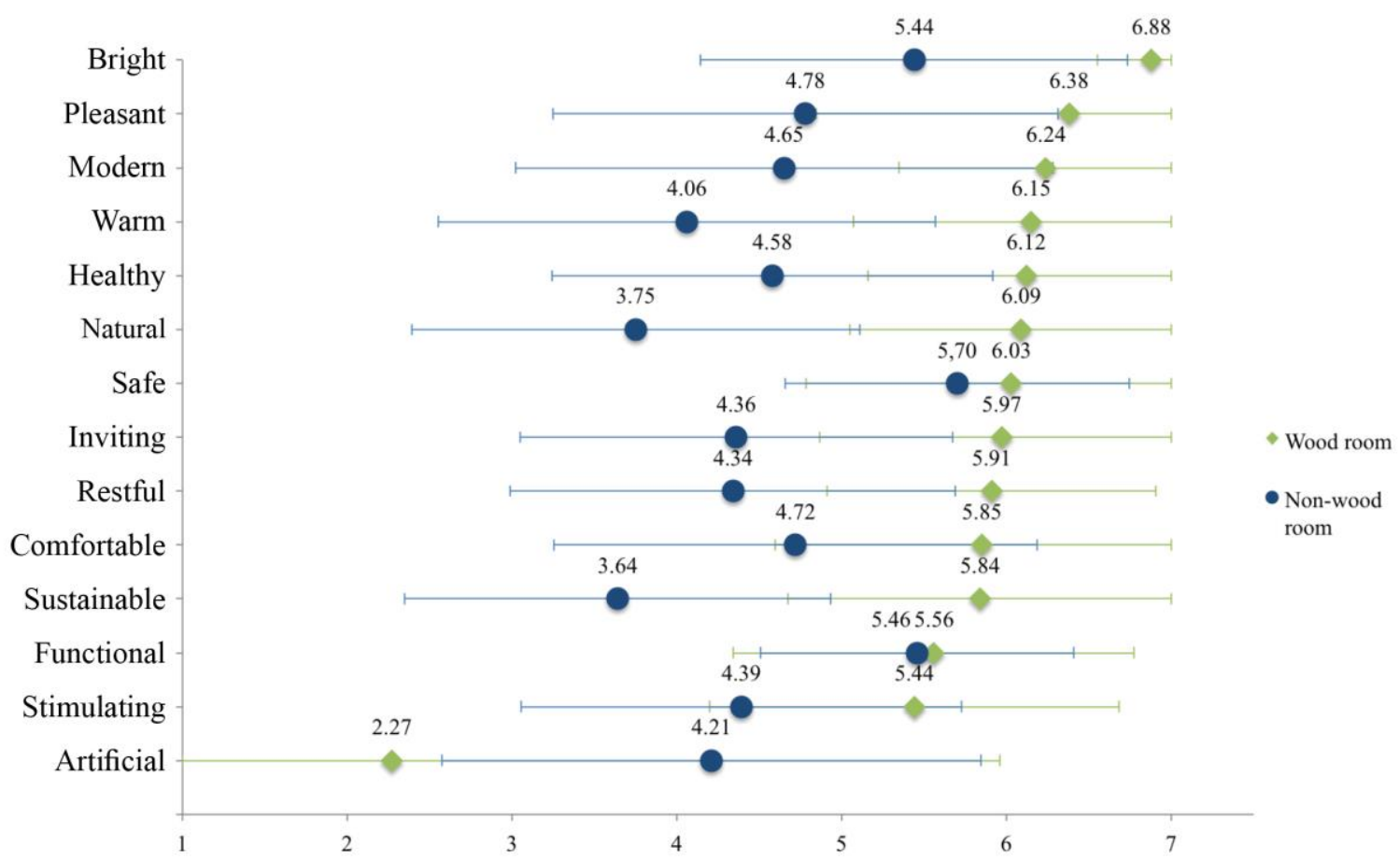

Fig. 3. Comparison of the mean perception scores for the adjectives describing the wood and non-wood rooms ( $1=$ does not describe the room well, $7=$ describes the room well)

The adjectives with the highest mean scores in the wood room were bright, pleasant, modern, warm, healthy, and natural. In the room without interior wood finishes, the five adjectives with the highest scores were bright, safe, functional, pleasant, and comfortable. The adjectives seen as describing the non-wood room the least (mean scores under the mid-point of the scale) included natural and sustainable. The only adjective not perceived to describe the wood room well was artificial, which was consistent with the results for its antonym, natural, which described the room well. These findings were consistent with the work of Fell (2010), who found that a wooden room was described as more natural and warm than its non-wood counterpart. The presence of interior wood finishes has been shown to improve the colour temperature of an entire space by creating a warmer visual ambiance (Jafarian et al. 2016; Watchman et al. 2017). As shown in a previous study of these rooms (Watchman et al. 2017), the wood room had higher $b^{*}$ values, which indicated a space that was more yellowish, warm in comparison with the bluish, cold colouring of the non-wood room (Table 3). The occupant survey results indicated that the objectively measured difference in colour temperatures was also perceptible in the subjective evaluations of the rooms. A warmer colour also corresponded to a greater sensitivity of the eye to light at higher $b^{*}$ values, which may have resulted in the perception of brighter environments, and explained the high mean score in the wood room for the adjective bright.

The perception of wood as modern was a surprising finding, and was in contrast with the work by Rice et al. (2006), where participants perceived wood as less modern, and more contemporary with other interior finishes. In architecture, the adjective modern is associated with modernism, a style in the arts, while the attribute contemporary refers to current trends. This distinction may have been unclear, which resulted in modern being understood as relating to the present or current times, as opposed to the past. In future questionnaire studies on wood perception this distinction should be clarified. The 
perception of occupants of the wooden multifunctional room may also have been influenced by contextual factors, such as the building's recent construction (2004) in comparison with other buildings on campus, such as the Alphonse-Desjardins building that was built in 1994, in which the non-wood room was located. In analysing the perception of wood, the feedback of the occupants must be considered within its cultural context. Masuda (1992) showed that wood products with knots are described as natural and rustic in Europe and North America, whereas in Japan, they are seen as defects associated with cheapness. Each building material has its own unique physical properties that are constant and measurable. However, its cultural properties vary by context, occupant, and with time.

\section{Table 3. $b^{*}$ Values in the Wood and Non-wood Rooms}

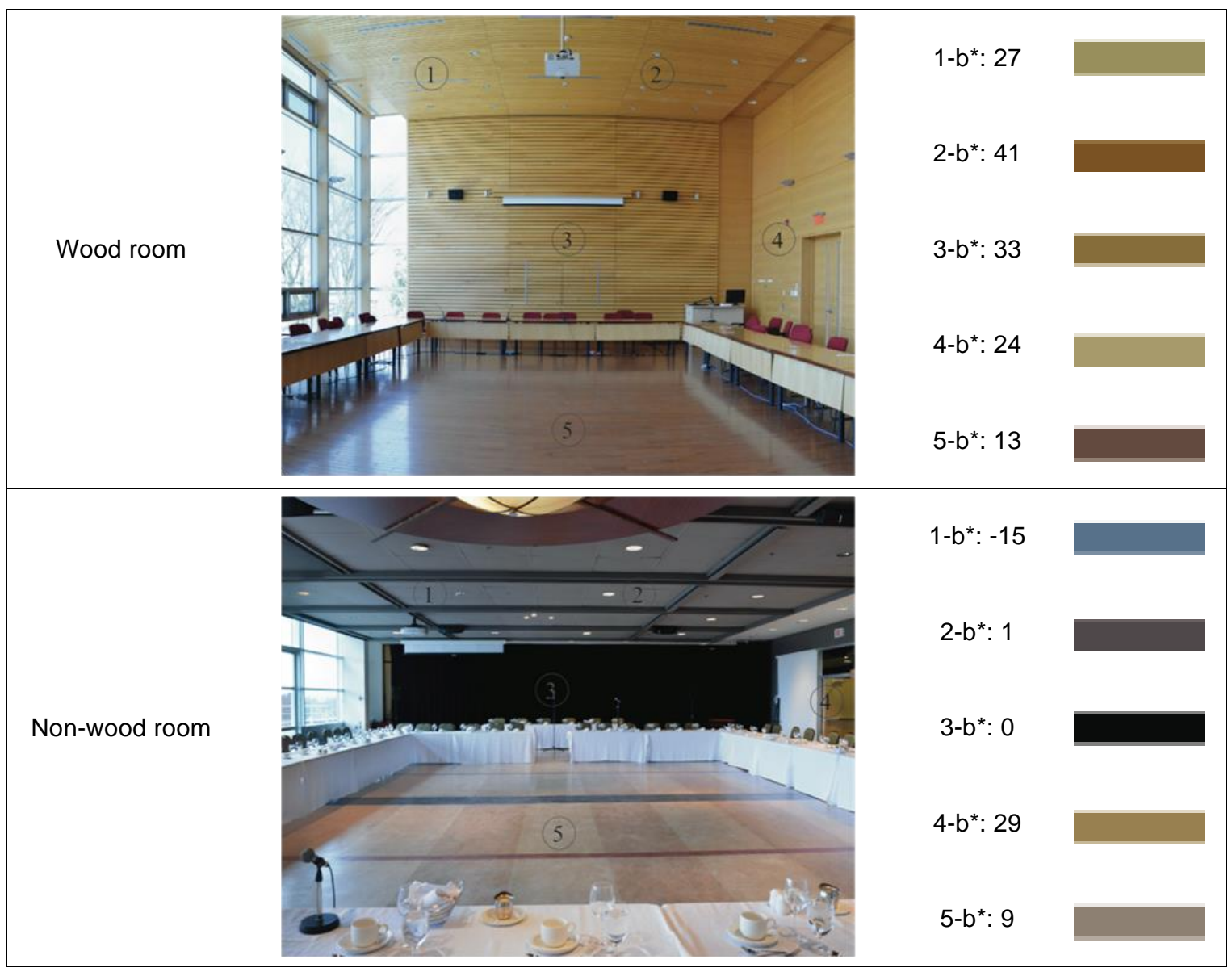

Pallasmaa in Holl et al. (2006) suggested that natural materials, such as stone, brick, and wood, convince the observer of their authenticity because their surfaces express their age and history. In contrast, synthetic materials do not convey their essence or age to the observer. The perception scores of the occupants in this comparative study tended to indicate an ambivalence about the artificial interior finishes in the non-wood room, while the naturalness of wood appeared to be undisputed. Comparing the votes for artificial with its antonym natural in the same room revealed a greater disparity between these terms in the wood room than in the non-wood room. Generally, occupants thought the term natural described the wood room well $(\mathrm{M}=6.09, \mathrm{SD}=1.042)$ compared with their rating of the term artificial $(\mathrm{M}=2.27, \mathrm{SD}=1.420)$. However, the number of votes 
for natural $(\mathrm{M}=3.75, \mathrm{SD}=1.360)$ and artificial $(\mathrm{M}=4.21, \mathrm{SD}=1.635)$ were similar in the non-wood room.

The similar perception by occupants of the adjectives safe and functional for both rooms may have indicated that the choice of the interior finishes has little influence on the perception of safety and functionality in meeting spaces. Although the term safe generally described the wood room $(\mathrm{M}=6.03, \mathrm{SD}=1.533)$ more than the non-wood room $(\mathrm{M}=5.70, \mathrm{SD}=1.045)$, the difference between the two rooms was not statistically significant $(\mathrm{p}=0.249)$. The same conclusion applied for the adjective functional $(\mathrm{p}=$ 0.693). These adjectives suggested translations of visual impressions into the potential inhabitability of the spaces, and therefore referred to non-experimented atmospheres related to wood. Future questionnaire studies could replace these two adjectives with better-suited material descriptors.

\section{Perception of Materials and Interior Finishes}

Most respondents considered the presence of wood surfaces to be satisfactory. The participants evaluated a series of factors that qualified the interior finishes on a scale of 1 (unsatisfactory) to 7 (satisfactory) (Fig. 4). The differences between the satisfaction scores of both rooms were found to be statistically significant for all of the factors, according to the independent $\mathrm{t}$-test. Material quality $(\mathrm{p}=0.000)$ and durability $(\mathrm{p}=$ 0.000 ) were seen as more satisfactory in the wood room than in the non-wood room. This was also the case for the overall appearance and image of the room $(\mathrm{p}=0.000)$.

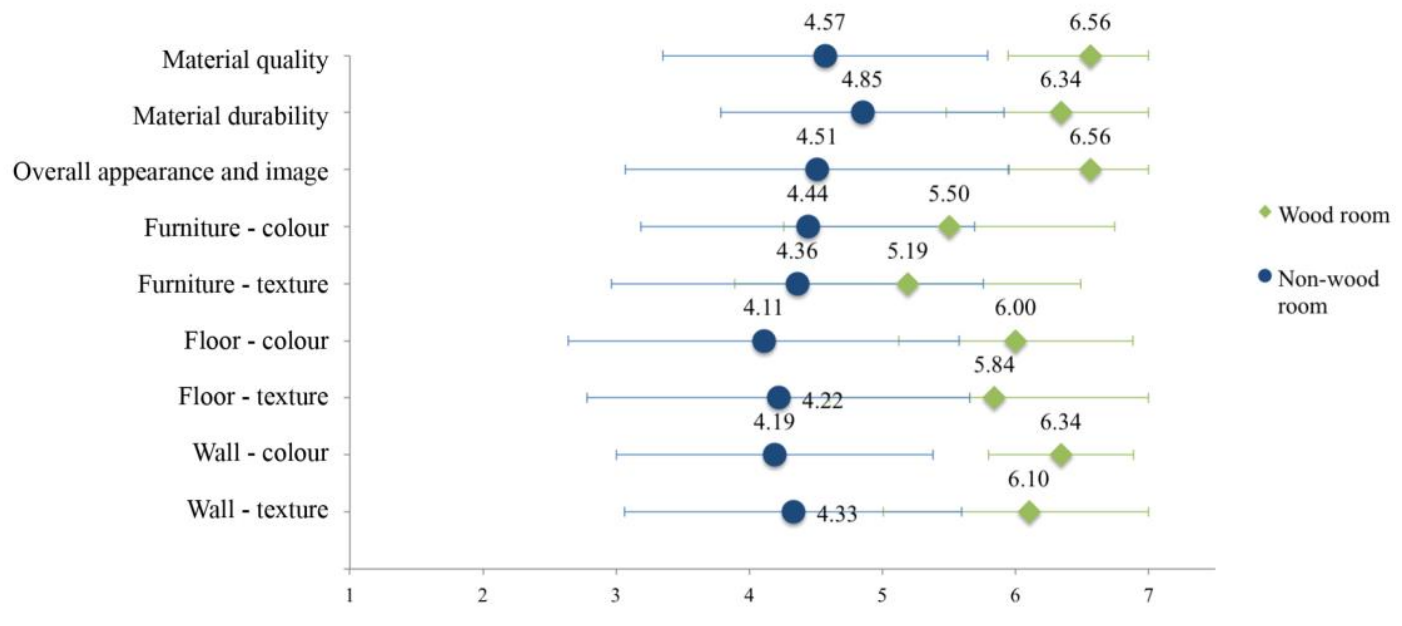

Fig. 4. Comparison of the mean perception scores for the interior finishes in the wood and nonwood rooms ( 1 = unsatisfactory, 7 = satisfactory $)$

The colour and texture of an interior finish can influence the perception of the built environment because every building material absorbs, reflects, or transmits light differently depending on its colour, finish, and reflectivity. In the wood room, the respondents found the colour and texture of the walls to be more satisfactory than the floor, which in turn surpassed the evaluation of the furniture (Table 4). More specifically, the colour was perceived as more satisfactory than the texture of the material in each of these pairs. This preferential distinction was not as readily expressed in the mean scores of the non-wood room, where the data fit within a narrow range. This indicated that the 
occupants were neither dissatisfied nor satisfied with the artificial finishes in the nonwood room, but rather indifferent or showed a neutral opinion towards the materials.

Table 4. Photographs of the Surfaces in the Wood (top) and Non-wood (bottom) Rooms

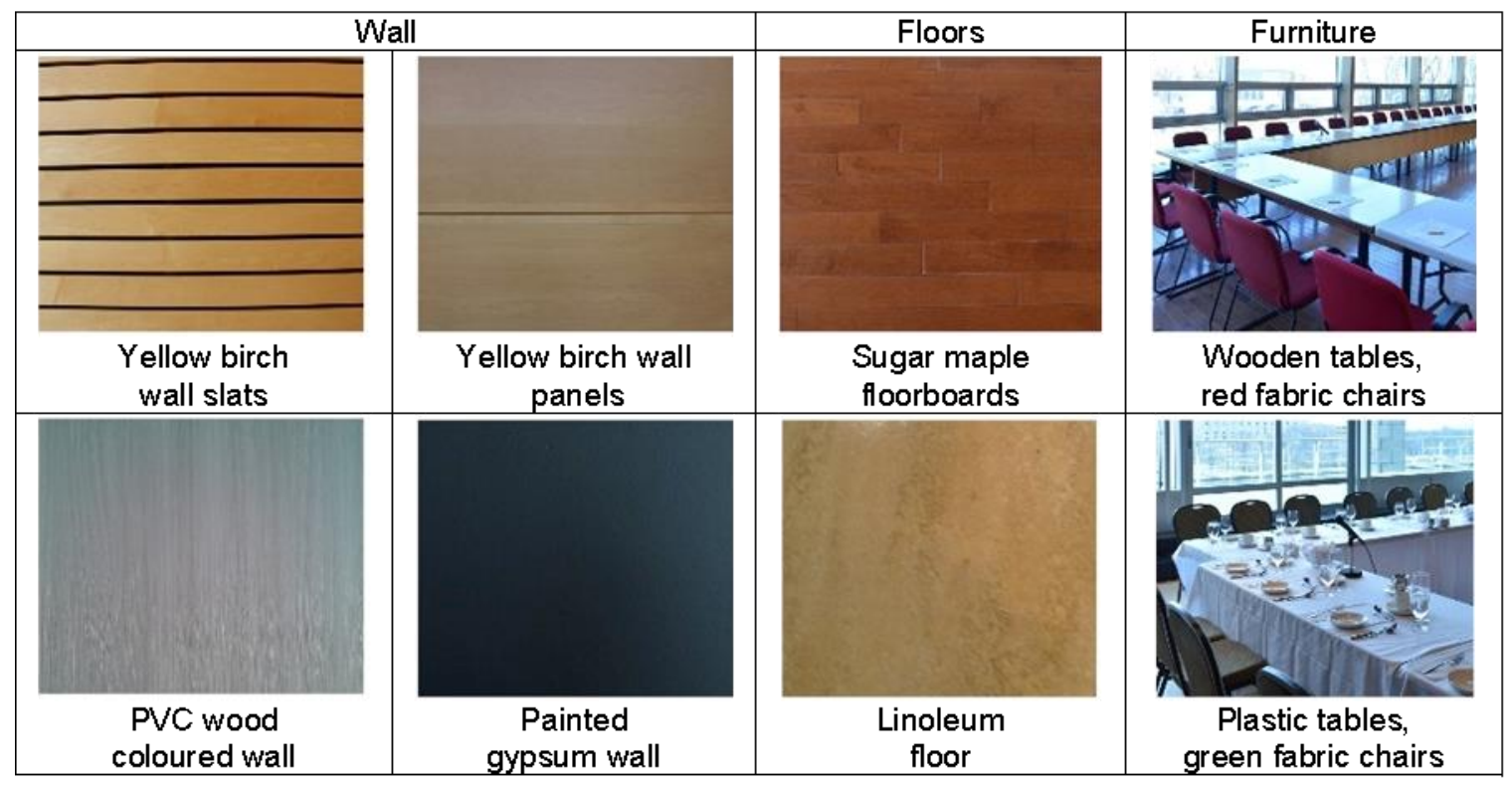

The yellow wood surfaces were preferred over the darker finishes of the same materials. The light-coloured decorative yellow birch panels on the walls in the wood room received a higher satisfaction score than the darker sugar maple floorboards (Fig. 4). This observation was consistent with the findings of Poirier et al. (2017). In a comparative study of five models with distinctive colours and positions of wood finishes, participants most preferred the bright models with yellow wood surfaces, describing them as luminous, natural, warm, and pleasant, and least preferred the darker model made with dark walnut wood surfaces, which were described as dark, unpleasant, and dazzling. This indicated the importance of the choice of the appropriate wood colour, texture, and position in the room for the desired visual ambiance.

\section{Occupant Perception of Comfort}

The occupants evaluated the lighting conditions, air quality, temperature, and noise levels in both rooms on a seven-point differential semantic scale. Higher scores did not necessarily express higher satisfaction levels for all of the questions. The best score was one when air was qualified as either odourless (1) or smelly (7). Four represented the best score when occupants decided if the temperature was too hot (1) or too cold (7). Seven was the best score when the occupants evaluated if they were dissatisfied (1) or satisfied (7) with the environmental conditions.

\section{Comfort perception of the wood room}

The satisfaction towards the overall lighting received the highest mean score $(\mathrm{M}=$ $6.57, \mathrm{SD}=0.690$ ) in the wood room, which was also perceived to have high levels of natural light $(\mathrm{M}=4.96, \mathrm{SD}=1.255)$ (Table 5). Surprisingly, the mean score for glare caused by artificial light sources totalled $2.65(\mathrm{SD}=1.922)$, even though no artificial 
lights were turned on. This could have indicated an unfamiliarity of the occupants with the notion of glare, or simply perhaps the activity of reading and writing taking place at that moment was not as demanding as in a regular situation involving a more extended period of performance. These findings suggested the need for clarification in future research and the inclusion of a longer period to practice more demanding activities, such as reading and writing, to validate the results.

Table 5. Wood Room: Means and Standard Deviations (SD) of the Perception Scores of the Occupants for Each Factor

\begin{tabular}{|c|c|c|c|c|c|c|c|}
\hline Factor & Mean & SD & $n$ & Factor & Mean & SD & $n$ \\
\hline Overall comfort & 6.00 & 0.964 & 29 & \multicolumn{4}{|l|}{ Noise } \\
\hline \multicolumn{4}{|l|}{ Lighting } & Noise overall & 5.00 & 1.305 & 28 \\
\hline Lighting overall & 6.57 & 0.690 & 28 & Noise level - silent/loud ${ }^{4}$ & 3.44 & 1.281 & 27 \\
\hline $\begin{array}{l}\text { Natural light - too } \\
\text { little/much } 4\end{array}$ & 4.96 & 1.255 & 27 & $\begin{array}{l}\text { From colleagues - } \\
\text { low/loud }^{1}\end{array}$ & 3.15 & 1.703 & 27 \\
\hline $\begin{array}{l}\text { Artificial light - too } \\
\text { little/much } 4\end{array}$ & 4.00 & 0.764 & 25 & $\begin{array}{l}\text { From ventilation systems - } \\
\text { low/loud } 1\end{array}$ & 3.26 & 1.607 & 27 \\
\hline $\begin{array}{l}\text { Sun and sky glare - } \\
\text { none/too much } 1\end{array}$ & 2.67 & 1.922 & 27 & From inside - low/loud ${ }^{1}$ & 2.70 & 1.295 & 27 \\
\hline $\begin{array}{l}\text { Artificial light glare - } \\
\text { none/too much } 1\end{array}$ & 2.65 & 1.495 & 26 & From outside - low/loud ${ }^{1}$ & 1.96 & 1.113 & 26 \\
\hline \multicolumn{4}{|l|}{ Air } & \multicolumn{4}{|l|}{ Temperature } \\
\hline Air - still/draughty 4 & 3.81 & 1.386 & 26 & $\begin{array}{c}\text { Temp - } \\
\text { uncomfortable/comfortable }\end{array}$ & 5.70 & 1.540 & 27 \\
\hline Air - dry/humid ${ }^{4}$ & 3.59 & 0.797 & 27 & Temp - too hot/cold ${ }^{4}$ & 4.50 & 0.860 & 26 \\
\hline Air- fresh/stuffy ${ }^{1}$ & 3.30 & 1.171 & 27 & Temp - stable/variable ${ }^{1}$ & 3.33 & 1.494 & 24 \\
\hline Air - odourless/smelly ${ }^{1}$ & 2.11 & 1.396 & 27 & Temp - overall & 6.00 & 1.038 & 27 \\
\hline
\end{tabular}

Note: Unless otherwise indicated, a score of 7 is 'best'; ${ }^{4}$ implies a score of 4 is best and ${ }^{1}$ implies a score of 1 is best

Comfort perception of the non-wood room

Satisfaction with the cleanliness of the room received the highest mean score $(\mathrm{M}$ $=5.71, \mathrm{SD}=1.219)$, followed by the overall satisfaction with the temperature $(\mathrm{M}=5.03$, $\mathrm{SD}=1.212)$ and lighting $(\mathrm{M}=5.00, \mathrm{SD}=1.435)$ for the non-wood room (Table 6$)$. Considering that very few questions received high scores in the non-wood room, it was believed that the positive evaluation of the cleanliness of the room stood out more than in the wood room. In comparison, the cleanliness score for the wood room was higher $(\mathrm{M}=$ $6.22, \mathrm{SD}=0.951$ ) than for the non-wood room.

The high overall satisfaction with the temperature and light levels was explained by subsequent elements in the questionnaire. Neither too hot nor too cold, the mean temperature vote was close to the mid-point of the scale $(\mathrm{M}=4.15, \mathrm{SD}=0.821)$, and was deemed more comfortable than uncomfortable. The occupants perceived, in almost equal part, the amount of natural light $(\mathrm{M}=4.68, \mathrm{SD}=1.536)$ and artificial light $(\mathrm{M}=4.26, \mathrm{SD}$ $=1.024)$ in the room. The noise from the ventilation systems was perceived as loud $(\mathrm{M}=$ $4.12, \mathrm{SD}=1.665)$, given that the best score was 1.00 . 
Table 6. Non-wood Room: Means and Standard Deviations (SD) of the Perception Scores of the Occupants for Each Factor

\begin{tabular}{|c|c|c|c|c|c|c|c|}
\hline Factor & Mean & SD & $n$ & Factor & Mean & SD & $n$ \\
\hline Overall comfort & 4.88 & 1.293 & 33 & \multicolumn{4}{|l|}{ Noise } \\
\hline \multicolumn{4}{|l|}{ Lighting } & Noise overall & 4.41 & 1.500 & 34 \\
\hline Lighting overall & 5.00 & 1.435 & 34 & Noise level - silent/loud ${ }^{4}$ & 4.30 & 1.237 & 33 \\
\hline $\begin{array}{l}\text { Natural light - too } \\
\text { little/much }{ }^{4}\end{array}$ & 4.68 & 1.536 & 31 & $\begin{array}{l}\text { From colleagues - } \\
\text { low/loud }^{1}\end{array}$ & 3.42 & 1.324 & 33 \\
\hline $\begin{array}{l}\text { Artificial light - too } \\
\text { little/much }{ }^{4}\end{array}$ & 4.26 & 1.024 & 34 & $\begin{array}{l}\text { From ventilation systems - } \\
\text { low/loud } 1\end{array}$ & 4.12 & 1.665 & 34 \\
\hline $\begin{array}{c}\text { Sun and sky glare - } \\
\text { none/too much }{ }^{1}\end{array}$ & 3.12 & 1.871 & 34 & From inside - low/loud 1 & 3.39 & 1.435 & 33 \\
\hline $\begin{array}{l}\text { Artificial light glare - } \\
\text { none/too much }{ }^{1}\end{array}$ & 2.88 & 1.629 & 34 & From outside - low/loud 1 & 2.15 & 1.520 & 34 \\
\hline \multicolumn{4}{|l|}{ Air } & \multicolumn{4}{|l|}{ Temperature } \\
\hline Air - still/draughty 4 & 3.79 & 1.647 & 34 & $\begin{array}{c}\text { Temp - } \\
\text { uncomfortable/comfortable }\end{array}$ & 4.91 & 1.466 & 33 \\
\hline Air - dry & .85 & 1.234 & 34 & Temp - too hot $/$ cold $^{4}$ & 4.15 & 0.821 & 34 \\
\hline Air-fresh/s & 3.79 & 1.274 & 34 & Temp - stable/variab & 3.59 & 1.365 & 32 \\
\hline Air - odourless/smelly ${ }^{1}$ & 3.33 & 1.633 & 33 & Temp - overall & 5.03 & 1.212 & 33 \\
\hline
\end{tabular}

Note: Unless otherwise indicated, a score of 7 is 'best'; ${ }^{4}$ implies a score of 4 is best and ${ }^{1}$ implies a score of 1 is best

\section{Comparison between the rooms}

Comparisons between the perceptions of the occupants of both rooms were able to be made, even though the rooms diverged for certain architectural aspects. The overall comfort satisfaction of the wood room $(\mathrm{M}=6.00, \mathrm{SD}=0.964)$ exceeded the mean satisfaction of the non-wood room $(M=4.88, S D=1.293)$. According to the MannWhitney test, the difference between these scores was statistically significant $(\mathrm{p}=0.001)$. This was consistent with the better overall lighting, noise, and temperature satisfaction scores in the wood room (Fig. 5).

The perception of the space went beyond the mere quantity of light to distinguish daylight from artificial light sources. The occupants perceived the wood room to be filled with more natural light and less artificial light than the non-wood room. This difference arose from the overall lighting satisfaction in the wood room $(\mathrm{M}=6.57, \mathrm{SD}=0.690)$, which significantly $(\mathrm{p}=0.000)$ exceeded the lighting satisfaction of the occupants in the non-wood room $(\mathrm{M}=5.00, \mathrm{SD}=1.435)$. Furthermore, a respondent in the non-wood room indicated the necessity to always turn on artificial lighting in the room (participant ADJ-14), whereas another participant mentioned that lighting levels were minimal (participant ADJ-34).

Although the key parameters of comfort mostly evaluated the physiological comfort of an individual, Cole et al. (2008) suggested that 'the psychological dimension of comfort is expanding from the provision of personal control to include the provision of daylighting, views of the outdoors, direct contact with nature, natural materials, etc.' The subjective evaluation of daylight in these rooms was consistent with the light levels measured for overcast skies in previous research. Watchman et al. (2017) measured an average daylight factor of $4.4 \%$ in the wood room, which was much higher in comparison with the $1.6 \%$ daylight factor in the non-wood room. 


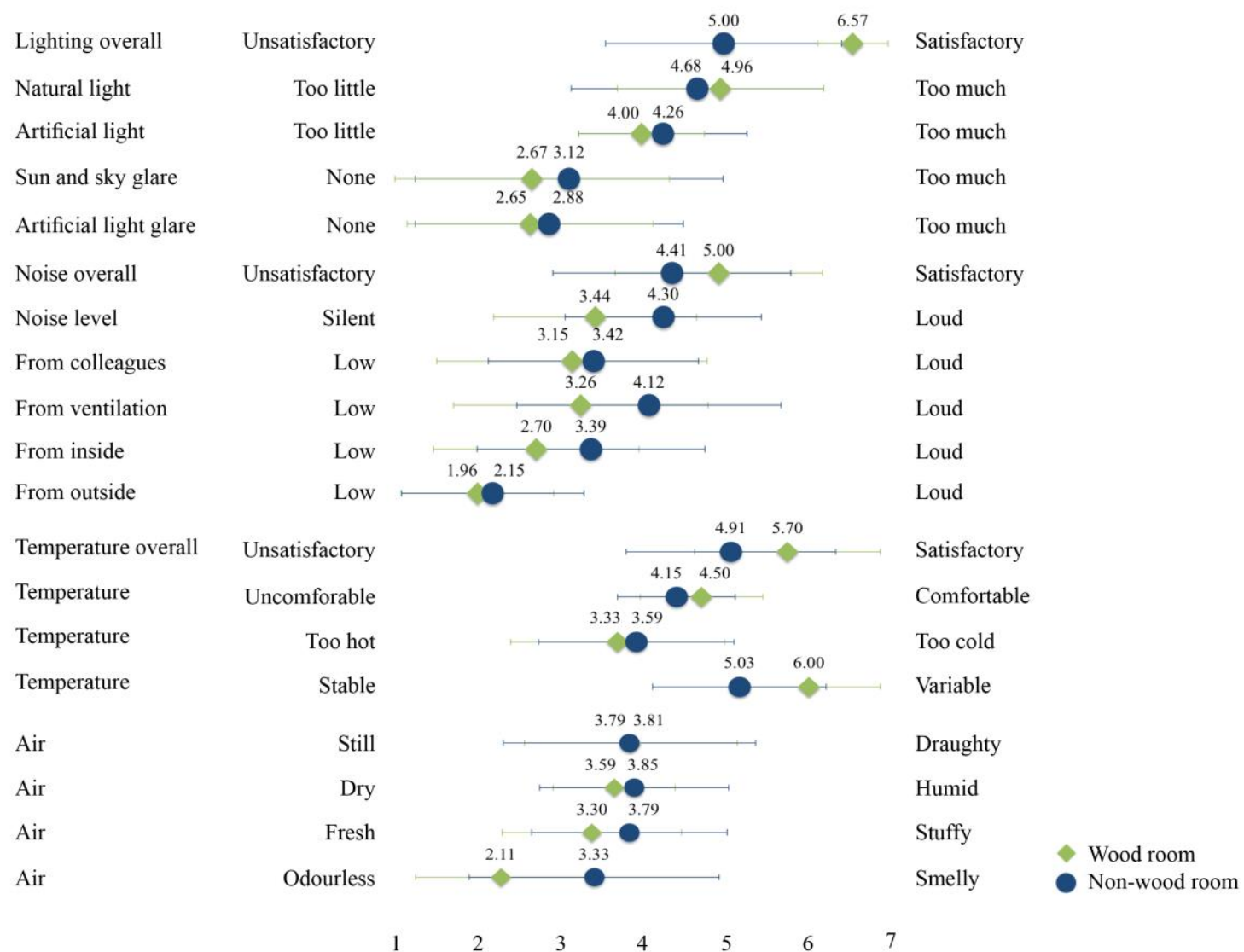

Fig. 5. Means of the perception scores of the occupants for the lighting, noise, temperature, and air categories of the questionnaire

For a space with substantial natural lighting (without electric lights), the average daylight factor in a room should not be less than 5\%, and the minimal acceptable level is 2\% (CIBSE 2015). The qualitative evaluation of the rooms by the occupants indicated that the distinction in daylight factors between these spaces was not only quantifiable, but also perceptible. The grey-scale images of the rooms show the distribution of light on the surfaces (Fig. 6). By removing the chromatic differences of the photographs in Adobe Photoshop the contrast intensity was more readily apparent (Demers 2007).

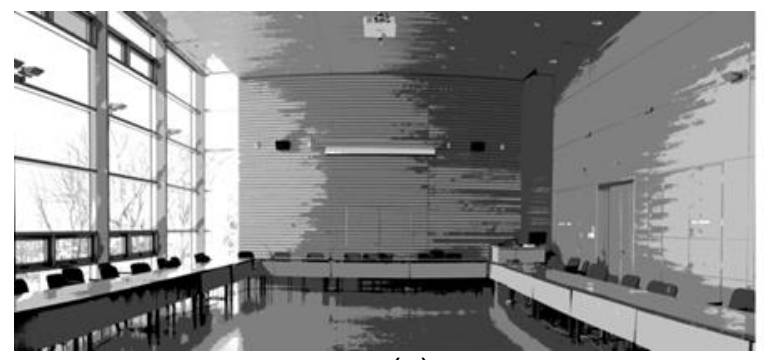

(a)

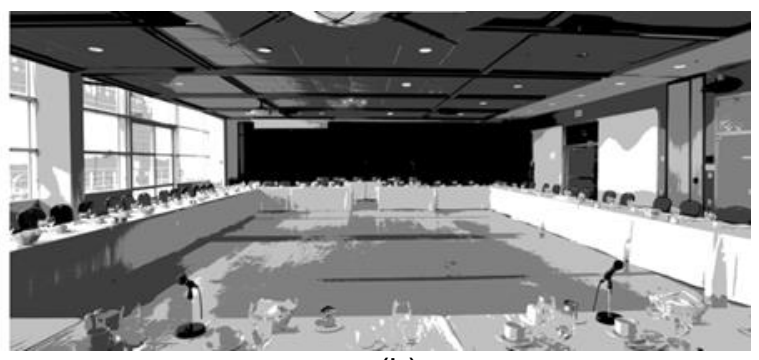

(b)

Fig. 6. Distribution of light in the grey-scale images of the (a) wood and (b) non-wood rooms

The occupants perceived the acoustic conditions in the wood room to be better than in the non-wood room. Even though the wood room $(\mathrm{M}=5.00, \mathrm{SD}=1.305)$ showed an increased overall noise satisfaction in comparison with the non-wood room $(\mathrm{M}=4.41$, 
$\mathrm{SD}=1.500)$, this difference was not statistically significant $(\mathrm{p}=0.127)$. The assessment of the noise level between silent and loud represented the only acoustic factor where statistically significant differences were observed $(\mathrm{p}=0.017)$. A respondent in the nonwood room mentioned difficulty hearing colleagues during meetings because of ventilation noises (participant ADJ-10). Another respondent would have liked to change seats because of these ventilation noises (participant ADJ-14). Two respondents in the wood room complained about echoes (participants GHK-16 and GHK-21).

The mean overall thermal comfort score in the wood room $(\mathrm{M}=6.00, \mathrm{SD}=$ 1.038) exceeded the mean value in the non-wood room $(\mathrm{M}=5.03, \mathrm{SD}=1.212)$, and this difference was statistically significant $(\mathrm{p}=0.002)$. The mean score in the non-wood room indicated that the room was perceived as neither too cold nor too warm (Fig. 5). Despite this neutral mean score $(\mathrm{M}=4.15, \mathrm{SD}=0.821)$, individual comments showed that three occupants brought and wore warmer clothing because they perceived the room to be generally cool. This highlighted the benefit of selecting occupants that have been in the case study rooms on numerous occasions, rather than recruiting participants to evaluate the indoor environmental quality after a limited amount of time spent in the rooms.

The air quality in both of the rooms was generally similar, as occupants found the air neither still nor draughty, neither dry nor humid, and neither fresh nor stuffy. The mean scores indicated a statistically significant difference $(\mathrm{p}=0.06)$ for the odourless/smelly factor. The non-wood room $(\mathrm{M}=3.33, \mathrm{SD}=1.633)$ was deemed smellier than the wood room $(\mathrm{M}=2.11, \mathrm{SD}=1.396)$, although both mean scores were under the mid-point of the scale.

\section{Satisfaction with the Rooms in General}

In terms of the overall satisfaction with the rooms, the occupants judged the wood room to be better than the non-wood room for five factors (Fig. 7). The means were different for the overall design $(p=0.000)$, commodities $(p=0.002)$, image $(p=0.001)$, and space use $(\mathrm{p}=0.002)$. Individual comments also expressed contrasting perceptions of the rooms. A respondent giving a score of three for the overall design in the non-wood room described the space as generally sad (participant ADJ-28). In the wood room, a respondent giving a score of six for the same question remarked that the presence of wood, high ceilings, and glazing were positive elements (participant GHK-19). Given that participants did not know that the research was aimed at studying the influence of wood on the comfort of occupants, the fact that wood was mentioned as a positive element in the overall design of the room indicated that choosing this material as an interior finish may positively influence the subjective perception of the space.

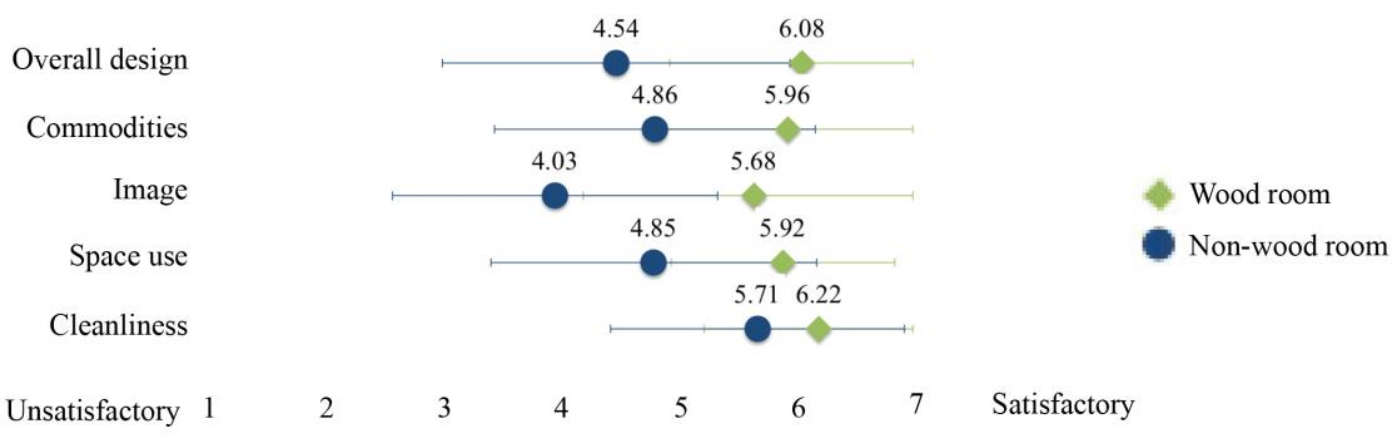

Fig. 7. Means of the perception scores of the occupants for each factor of the room in general 


\section{Participant Demographics}

Incomplete answers with regards to the participant demographic questions limited the precision of the description of the respondents. Questions regarding age, gender, and seating location in the room were placed in the last section of the questionnaire. However, response rates declined throughout the survey. It was hypothesised that some participants found the 15-min survey too long to complete. In laboratory settings, the recruited participants' sole task is to complete the questionnaire. However, the main task of the building occupants required their participation in a meeting, not the completion of the survey. Leaman (2003) suggested that most occupants consider buildings as a means to an end, and therefore have little interest in their design and management, as long as they do not cause inconveniences. Higher response rates from building occupants could therefore result from more concise questionnaires requiring limited answering time.

\section{Instrumental Comparison of the Environmental Conditions in Both Rooms}

The subjective perception of the occupants of the rooms was studied in relation to the measurements of the comfort parameters. The indoor conditions were similar in both of the occupied rooms, even though they were studied under distinct outdoor conditions, which was because of the week-long interval between meetings. The mechanical systems present in both rooms provided adequate conditions for occupant use and explained the similar indoor conditions measured (Table 7).

Table 7. Mean Environmental Conditions Measured in Both Rooms

\begin{tabular}{|c|c|c|}
\hline Parameter & Wood Room & Non-wood Room \\
\hline Ambient temperature & $22.6^{\circ} \mathrm{C}$ & $22.7^{\circ} \mathrm{C}$ \\
\hline Humidity level & $17.0 \%$ & $24.5 \%$ \\
\hline $\mathrm{CO}_{2}$ concentration & $484 \mathrm{ppm}$ & $536 \mathrm{ppm}$ \\
\hline Noise level & $49.4 \mathrm{dBa}$ & $57.4 \mathrm{dBa}$ \\
\hline Illuminance values & $696 \mathrm{lux}$ & $203 \mathrm{lux}$ \\
\hline
\end{tabular}

The mean temperature in the wood room was similar to the temperature in the non-wood room despite cooler outdoor temperatures during the study of the wood room. During the meeting in the wood room, an outdoor temperature of $6{ }^{\circ} \mathrm{C}$ and humidity level of $37 \%$ were recorded, whereas it was warmer $\left(12^{\circ} \mathrm{C}\right)$ and more humid $(46 \%)$ during the meeting in the non-wood room. The humidity level measured in the wood room was lower than in the non-wood room. This was consistent with the higher outdoor humidity during the meeting in the non-wood room. The mean carbon dioxide concentration in the wood room was $9.7 \%$ lower than the mean value in the non-wood room. Given the larger volume of the wood room $\left(1101.6 \mathrm{~m}^{3}\right)$ compared with the non-wood room $\left(809.2 \mathrm{~m}^{3}\right)$, a lower concentration was expected because the carbon dioxide emitted by the occupants was more diluted in the larger space. The mean noise level in the wood room was $13.9 \%$ lower than the level measured in the non-wood room.

Perhaps the most distinct environmental variable was related to the lighting of the spaces. The mean illuminance values measured in the wood room were 3.4 times higher than those in the non-wood room. The illuminance values measured in the wood room varied from 1165 lux near the window to 588 lux at the furthest point from the window $(M=696)$. In the non-wood room, the illuminance levels varied between 472 lux and 130 lux (M = 203). In the study by Watchman et al. (2017), the analysis of these multifunctional rooms on the same day under overcast skies showed that the mean 
illuminance level in the wood room was 2.7 times higher than in the non-wood room. The larger window area in the wood room $\left(96.7 \mathrm{~m}^{2}\right)$ than in the non-wood room $\left(42.7 \mathrm{~m}^{2}\right)$ explained this variation in the illuminance values. Also, it was shown that the interior finishes influenced the distribution of light in the rooms. Given the north-west orientation of the windows, only indirect sunlight entered both of the rooms. In the present study, the subjective perception of the occupants of the rooms was analysed on two separate days under different sky conditions for the same occupants to evaluate both rooms. Considering that the wood room had 2.7 times the illuminance level of the non-wood room under the same sky conditions, the 3.4 times higher illuminance level measured under different sky conditions was only partially explained by the different exterior conditions. Despite generally clear and sunny skies during the study of the wood room compared with the overcast and rainy conditions during the study of the non-wood room, more than two thirds of the higher illuminance levels measured in the wood room may have been because of the larger window area and uniform use of wood finishes.

Similar occupant comfort perceptions were expected for both rooms given the similar indoor conditions. However, the analysis of the self-assessed comfort of the occupants found higher thermal, lighting, acoustic, and overall comfort satisfaction levels in the wood room, as is illustrated in Fig. 5. Although the results of the study did not entirely allow for the drawing of conclusions without certain doubts that the indoor use of wood contributed to enhancing the environmental comfort of the occupants, several connections did seem plausible. The positive evaluation of the quality, durability, image, colour, and texture of the interior wood finishes, as well as the higher illuminance levels in the wood multifunctional room, were a possible explanation for the difference in comfort votes between the rooms, even though the instrumental data indicated similar interior environments. The subjective properties of wood may have positively influenced the evaluation of the wood room because, as was suggested by Humphreys (2005), 'building occupants balance the good features against the bad to reach their overall assessment'. Augustin and Fell (2015) also suggested that in the presence of wood, occupants tend to assume positive health benefits and have higher productivity levels. This may have resulted in higher tolerance levels towards comfort parameters in the wood room, which led to higher satisfaction scores and a more positive evaluation of the indoor environment.

The observations that emerged from this exploratory case study suggested the need for a deeper investigation into the interior finishes used in buildings. Comfort and architectural perceptions are contextual phenomena; therefore, the results of this study may not be applicable to other multifunctional rooms or other times of the year. Furthermore, the psychological effects of parameters distinct from interior finishes, such as room height, views, and amount of daylight coming through tall windows, could also have affected comfort perception in this study. Future research could focus on evaluating a larger selection of spaces on a number of occasions with different groups to study the perception of wood in built environments in more depth. Focus groups could also be of interest to further determine how occupants describe interior finishes, such as the introduction of a narrative data acquisition process. This would also allow discussions during which notions, such as glare, and qualifiers, like modern and contemporary, could be clarified. Future POEs should consider the potential of integrating material adjectives to provide more feedback on biophilic materials, such as wood, and to highlight the importance of the choice of interior finish when designing workspaces. 


\section{CONCLUSIONS}

This exploratory research introduced a new survey instrument specifically adapted to produce highly valuable findings on the preferences of occupants in relation to the use of indoor wood finishes in architecture. Studying the influence of interior finishes on environmental comfort in a post-occupancy framework illustrated that the subjective qualities of wood can positively influence the evaluation of a space. The research was innovative by integrating a series of adjectives that were developed to evaluate impressions provided by the experience of a space in relation to interior finishes. This research proposed a study of two similar multifunctional rooms designed with different interior finishes in different buildings. Additionally, the rooms were evaluated by a single group consisting of 36 participants, which provided promising and indicative results.

1. The perception of the wood room by the occupants was that it was brighter, more pleasant, modern, warm, healthy, natural, inviting, restful, comfortable, sustainable, and stimulating. It was found that the only adjective to describe the non-wood room better than the wood room was artificial. No differences between the rooms were observed for the adjectives safe and functional.

2. The quality and durability of the interior finishes, as well as the overall look of the room, were perceived to be more satisfying in the wood room than in the non-wood room. The occupants indicated a greater satisfaction with the colour and texture of the furniture, floor, and walls in the wood room.

3. Higher overall comfort satisfaction scores were observed in the wood room, even though instrumental measurements of the interior conditions in both rooms revealed similarities in terms of the ambient temperature, relative humidity, carbon dioxide concentrations, and noise levels. The main difference was found with the illuminance levels, which was explained by a combination of the window area and interior finish reflectance, rather than the varying sky conditions during the study. The higher satisfaction levels in the wood room suggested that the presence of wooden interior finishes contributed to a positive occupant experience in the room.

\section{ACKNOWLEDGMENTS}

The authors are grateful to the Natural Sciences and Engineering Research Council of Canada for the financial support through its IRC No. 461745 and CRD No. 445200 programs (MSc RDC 17), as well as the industrial partners of the NSERC industrial chair on eco-responsible wood construction (CIRCERB). The authors would like to thank all of the members of Laval University's teachers' union who participated in this study. The authors wish to thank Adrian Leaman for the license to use the BUS survey methodology in this case study. 


\section{REFERENCES CITED}

American Society of Heating, Refrigerating and Air-conditioning Engineers (ASHRAE) (2013). ASHRAE Handbook - Fundamentals, American Society of Heating, Refrigerating and Air-Conditioning Engineers, Atlanta, GA.

Augustin, S., and Fell, D. (2015). Wood as a Restorative Material in Healthcare Environments, FPInnovations, Québec City, Canada.

Broman, N. O. (2001). "Aesthetic properties in knotty wood surfaces and their connection with people's preferences," J. Wood Sci. 47(3), 192-198. DOI: 10.1007/BF01171221

Burnard, M., and Kutnar, A. (2015). "Wood and human stress in the built indoor environment: A review," Wood Sci. Technol. 49(5), 969-986. DOI: 10.1007/s00226015-0747-3

BUS Methodology - History (2016). "History,” Building Use Studies Methodology, (http://www.busmethodology.org/history/), Accessed 27 April 2016.

Candido, C., Kim, J., de Dear, R., and Thomas, L. (2016). "BOSSA: A multidimensional post-occupancy evaluation tool," Build. Res. Inf. 44(2), 214-228. DOI:

10.1080/09613218.2015.1072298

CIBSE (2015). Guide A: Environmental Design, Chartered Institution of Building Service Engineers, London, UK.

Cole, R. J., Robinson, J., Brown, Z., and O'Shea, M. (2008). "Re-contextualizing the notion of comfort," Build. Res. Inf. 36(4), 323-336. DOI:

10.1080/09613210802076328

Demers, C. M. H. (2007). "A classification of daylighting qualities based on contrast and brightness analysis," in: Conference Proceedings of the American Solar Energy Society (ASES), SOLAR 2007, Cleveland, OH, pp. 243-252.

Demers, C. M. H., and Potvin, A. (2016). "From history to architectural imagination: A physical ambiences laboratory to interpret past sensory experiences and speculate on future spaces," Ambiances, (https://ambiances.revues.org/756), Accessed 11 January 2017.

Deuble, M. P., and de Dear, R. J. (2014). "Is it hot in here or is it just me? Validating the post-occupancy evaluation," Intelligent Buildings International 6(2), 112-134. DOI: 10.1080/17508975.2014.883299

Elliot, A.C., and Woodward, W.A. (2007). Statistical Analysis Quick Reference Guidebook with SPSS Examples, Sage Publications, Thousand Oaks, CA.

Fell, D. R. (2010). Wood in the Human Environment: Restorative Properties of Wood in the Built Indoor Environment, Ph.D. Dissertation, University of British Columbia, Vancouver, Canada.

Frontczak, M., Schiavon, S., Goins, J., Arens, E., Zhang, H., and Wargocki, P. (2012). "Quantitative relationships between occupant satisfaction and satisfaction aspects of indoor environmental quality and building design," Indoor Air 22(2), 119-131. DOI: 10.1111/j.1600-0668.2011.00745.x

Galatioto, A., Leone, G., Milone, D., Pitruzzella, S., and Franzitta, V. (2013). "Indoor environmental quality survey: A brief comparison between different post occupancy evaluation methods," Advanced Materials Research 846-867, 1148-1152. DOI: 10.4028/www.scientific.net/AMR.864-867.1148 
Ghasemi, A., and Zahediasl, S. (2012). "Normality tests for statistical analysis: A guide for non-statisticians," International Journal of Endocrinology and Metabolism 10(2), 486-489. DOI: 10.5812/ijem.3505

Holl, S., Pallasmaa, J., and Pérez Gomez, A. (2006). Questions of Perception: Phenomenology of Architecture, William Stout Publishing, San Francisco, CA.

Humphreys, M. A. (2005). "Quantifying occupant comfort: Are combined indices of the indoor environment practicable?," Build. Res. Inf. 33(4), 317-325. DOI: $10.1080 / 09613210500161950$

Jafarian, H., Demers, C. M. H., Blanchet, P., and Laundry, V. (2016). "Impact of indoor use of wood on the quality of interior ambiances under overcast and clear skies: Case study of the Eugene H. Kruger Building, Québec City," BioResources 11(1), 16471663. DOI: 10.15376/biores.11.1.1647-1663

Leaman, A. (2003). "User needs and expectations," in: Buildings, Culture \& Environment: Informing Local \& Global Practices, R. J. Cole and R. Lorch (eds.), Blackwell Publishing, Hoboken, NJ, pp. 154-176.

Marans, R.W., and Yan, X. (1989). "Lighting quality and environmental satisfaction in open and enclosed offices," Journal of Architectural and Planning Research 6(2), 118-131.

Masuda, M. (1992). "Visual characteristics of wood and the psychological images," Bulletin of the Kyoto University Forests 38(12), 1075-1081.

Nyrud, A. Q., and Bringslimark, T. (2010). "Is interior wood use psychologically beneficial? A review of psychological responses toward wood," Wood Fiber Sci. 42(2), 202-218.

Pallant, J. (2016). SPSS Survival Manual (6th ed.), Open University Press, Maidenhead, UK.

Peretti, C., and Schiavon, S. (2011). "Indoor environmental quality surveys. A brief literature review," Center for the Built Environment, (http://escholarship.org/uc/item/0wb1v0ss), Accessed 13 January 2016.

Poirier, G., Demers, C. M. H., and Potvin, A. (2017). "Experiencing wooden ambiances with Nordic light: Scale model comparative studies under real skies," BioResources 12(1), 1924-1942. DOI: 10.15376/biores.12.1.1924-1942

Potvin, A. (2000). "Assessing the microclimate of urban transitional spaces," in: Proceedings of PLEA 2000 (Passive Low Energy Architecture), James and James Science Publishers, Cambridge, UK.

Preiser, W. F. E., Rabinowitz, H. Z., and White, E. T. (1988). Post-occupancy Evaluation, Van Nostrand Reinhold, New York, NY.

Rice, J., Kozak, R. A., Meitner, M. J., and Cohen, D. H. (2006). “Appearance wood products and psychological well-being," Wood Fiber Sci. 38(4), 644-659.

Ridoutt, B. G., Ball, R. D., and Killerby, S. K. (2002). "First impressions of organizations and the qualities connoted by wood in interior design," Forest Prod. J. 52(10), 30-36.

Schiavon, S., and Altomonte, S. (2014). "Influence of factors unrelated to environmental quality on occupant satisfaction in LEED and non-LEED certified buildings," Build. Environ. 77, 148-159. DOI: 10.1016/j.buildenv.2014.03.028

Tsunetsugu, Y., Miyazaki, Y., and Sato, H. (2007). "Physiological effects in humans induced by the visual stimulation of room interiors with different wood quantities," $J$. Wood Sci. 53(1), 11-16. DOI: 10.1007/s10086-006-0812-5 
Watchman, M., Potvin, A., and Demers, C. M. H. (2017). "Wood and comfort: A comparative case study of two multifunctional rooms," BioResources 12(1), 168-182. DOI: 10.15376/biores.12.1.168-182

Article submitted: May 8, 2017; Peer review completed: August 3, 2017; Revised version received: September 28, 2017; Accepted: September 29, 2017; Published: October 3, 2017.

DOI: $10.15376 /$ biores. $12.4 .8704-8724$ 